\title{
Geçiş Mekanlarının Hareket, Mekân ve Kullanım Ekseninde Kent Günlüğü Üzerinden Okunması
}

\author{
Elif SAĞLIK ${ }^{1 *}$ (D) , Rozerin ÇELIK ${ }^{2}$ (D) \\ ORCID 1: 0000-0002-5230-3869 \\ ORCID 2: 0000-0001-7237-1466 \\ ${ }^{1}$ Çanakkale Onsekiz Mart Üniversitesi, Mimarlık ve Tasarım Fakültesi, Peyzaj Mimarlığı Bölümü, 17100, \\ Çanakkale, Türkiye. \\ ${ }^{2}$ Çanakkale Onsekiz Mart Üniversitesi, Fen Bilimleri Enstitüsü, Peyzaj Mimarlığı Ana Bilim Dalı, 17100, \\ Çanakkale, Türkiye. \\ *e-mail: elifysaglik@gmail.com
}

Öz

Kentlerin şekillenmesinde etkili olan doğal veriler aynı zamanda kentin günlüğünde de önemli yer tutmaktadır. Bu bağlamda; içinden su geçen kentlerde, kentin ayrı bölgelerini birleştiren geçiş mekânları ön planda yer almaktadır. Hareket, mekân ve kullanım kavramları ekseninde geçiş mekânlarının değerlendirilmesi ile kent günlüğünde yeri ortaya çıkmaktadır. Çalışma kapsamında; Çanakkale kent merkezinde bulunan ve kenti ikiye bölen Sarıçay'ın üzerinde konumlanmış olan köprüler materyali oluşturmaktadır. Yaya ve taşıt trafiğinin birlikte kurgulandığı ya da sadece yaya kullanımına açık geçiş mekânları hareket, mekân ve kullanım odaklı formülasyonu ile incelenmiştir. Incelemeye ilişkin bulgular sonucunda geçiş mekânlarının formülasyon kapsamında erişilebilirlik, yürünebilirlik ve ulaşılabilirlik kavramları ile doğrudan bağlantılı olduğu ve kent günlüğünde dış mekân yaşantısını kolaylaştırdığı; kentin kimliğine katkı sunmadığı sonucuna varılmıştır.

Anahtar Kelimeler: Geçiş mekânı, kent günlüğü, köprü, Sarıçay

\section{Reading the Transition Spaces on the Axis of Movement, Space and Use through the City Diary}

\begin{abstract}
Natural data, which are effective in shaping cities, also have an important place in the city's diary. In this context, in cities with water flowing through, the transition spaces connecting the separate parts of the city are in the foreground. With the evaluation of the transition spaces in the axis of movement, space and usage concepts, its place in the city diary emerges. Within the context of work, the bridges located over Sarıçay, which is located in the city center of Çanakkale and divides the city into two, constitute the material. Transition spaces, where pedestrian and vehicle traffic are designed together or only open to pedestrian use, have been examined with their formulation focused on movement, space and use. As a result of the findings related to the examination, it has been concluded that transition spaces are directly related to the concepts of accessibility, walkability and reachability within the scope of the formulation and facilitate outdoor life in the city diary and do not contribute to the identity of the city.
\end{abstract}

Keywords: Transition place, urban diary, bridge, Sarıçay

Citation / Atıf: Sağlık, E. and Çelik, R. (2021). Geçiş mekanlarının hareket, mekân ve kullanım ekseninde kent günlüğü üzerinden okunması. Journal of Architectural Sciences and Applications, 6 (2), 607-620. DOI: https://doi.org/10.30785/mbud.969754 


\section{Giriş}

Peyzaj mimarlığı meslek disiplini doğrultusunda yapılan tasarımların temel ilkesi insandır. Kullanıcıların ihtiyaç ve gereksinimleri mekân tasarımlarında en önemli bileşendir. Bu nedenle fiziksel, sosyal ve psikolojik etmenler mekân oluşumunu etkileyen unsurlar olarak karşımıza çıkmaktadır (Bekçi, 2006). Insanlar algısal sistem ile mekân konusunda bilgi sahibi olurlar. Mekânlar fonksiyonel, güvenli, eğitici ve koruyucu olmakla birlikte üzerinde gerçekleştirilen faaliyetlere olanak sağlamalıdır. Peyzaj bileşenleri yardımıyla mekânlar, kullanımı hakkında bilgi veren nitelik taşımalıdır. Böylelikle insanlar mekânı daha çekici bulmaktadır (Aslantaş, 1998). Kullanıcıların bu bilgiler ışı̆̆ında mekân olarak algıladıkları bölgelerin birleşmesi sonucunda kentler oluşmaktadır.

Insan algısı, yapı ve birçok peyzaj bileşeni kentlerin oluşumunda rol oynamaktadır (Aslantaş, 1998). Kent, sürekli gelişim içinde olan, halkın ihtiyaç ve gereksinimlerini karşılayan, tarımsal faaliyetlerin az gerçekleştiği, nüfus yoğunluğunun fazla olduğu yerleşim birimidir (Keleş, 2006). Kentler dinamik bir yapı olmakla beraber gelişen ve değişen yerleşim alanlarıdır (Toprak, 2003; Karakaya, 2013). Kentlerde bulunan farklı kültür ve yaşayış biçimleri kent olgusunu şekillendirmekte ve nitelik kazandırmaktadır (Karakaya, 2013). Kent içi peyzaj tasarımlarının birleşimiyle kentsel tasarım kavramı ortaya çıkmaktadır.

Kentsel tasarım; farklı ölçeklerde kentin doğal ve kültürel yapısı, sosyo-ekonomik durumu, tarihsel dokusu gibi birçok faktörü yansıtan, kent mobilyaları ve siluetiyle örtüşen projelerin tümüdür (ÇŞB, 2013). Kentsel tasarım; alan içinde bulunan kullanımlara ilişkin çözüm önerileri geliştiren planlı çalışmalardır (Altaban, 2013). Kullanıcılar kentte yaptıkları aktivite ve taşıdıkları niteliklere göre farklı özelliklere sahip mekân oluşturur. Bu farklı özellikteki kent içi mekânları birbirine bağlayan ve tampon özelliği gösteren geçiş mekânları bulunmaktadır (Dizman, 2015).

Geçiş mekânları (ara mekân) mekân kurgusunu oluşturan, mekân sürekliliği sağlayan ve belli eylemler için alan oluşturan bölge olarak tanımlanmaktadır. Kullanım yoğunluğuna göre başlangıç noktası ve odak noktası bulunan özel ile geneli bütünleyici niteliktedir. Geçiş alanlarının kullanıcılar tarafından kavranabilen bir mekân olarak algılanmasında birçok peyzaj öge ve elemanlarının bilinçli bir araya getirilişleri önemli rol oynar (Dizman, 2015). Kentlerdeki geçiş mekânlarının düzensiz gelişimi ve değişimi kent dokusunu olumsuz yönde etkileyebilmektedir (Karakaya, 2013).

Kent içinde, hacim ve form olarak kolay algılanan ve estetik açıdan doğru tasarlandığı zaman etkili olan geçiş alanlarından en önemlisi ve dikkat çekeni köprülerdir. Köprü kavramı Türk Dil Kurumu (2021) tarafından "Herhangi bir engelle ayrılmış iki yakayı birbirine bağlayan veya trafik akımının, başka bir trafik akımını kesmeden üstten geçmesini sağlayan ahşap, kâgir, beton veya demir yapı" olarak tanımlanmıştır. Ansiklopedik Mimarlık Sözlüğünde ise bu kavram "(i) aralarında su, çukur arazi veya yol gibi engeller bulunan iki yakayı birbirine bağlayarak yolu bir yandan ötekine eriştirmek için yapılan ahşap, kâgir veya madeni yapı; (ii) iki binayı veya bir binanın iki parçasını birbirine bağlayan geçit" şeklinde tanımlanmaktadır (Hasol, 1995).

Suya kıyısı olan ya da içinden geçerek kenti bölen su ögesinin bulunduğu kentlerde yaşanan değişim ve gelişim süreci farklı bölgeleri birbirine bağlama ihtiyacını ortaya çıkarmaktadır. Bu nedenle köprüler çözüm noktasında başvurulan ilk kentsel yapı bileşeni olmaktadır. Kentsel öge olan köprüyü, Şahin (1983)'e göre, çok anlamlılık taşıyan bir mekânsal örtü olup "kentsel sirkülasyon" ve "kentsel donatım elemanı" olarak okumak mümkündür (Pakdamar ve İpekçi, 2019).

Köprülerin engelleri aşma, üzerinden geçip gitme, bağlama gibi fonksiyonları ile üzerinde durulan, seyir yapılan, kenti panoramik izleme sürecine durarak dâhil olunan bir kentsel alan özelliği de bulunmaktadır (Başdoğan ve Manisa, 2016). Bu nedenle kent siluetinde köprü ögesi güçlü ve estetik bir landmark, düğüm noktası olarak tasvir edilebilmekte ve kent günlüğünde yer bulmaktadır.

Avrupa'da içinden nehir geçen kentlerde geçiş mekanları kent dokusu için oldukça önemlidir. Kentle özdeşleşen, kent temsil eden imajlar olarak karşımıza çıkmaktadır. Paris'te Seine nehri üzerinde bulunan III. Alexandre Köprüsü (Pont Alexandre III) ve Hakeim Köprüsü (Pont de Bir-Hakeim), Prag'da Charles Bridge (Charles Köprüsü) ve Edirne'de bulunan Uzun Köprü (Taş Köprü) bu anlamda akla gelen ilk ve güçlü örneklerdir (Şekil 1). 


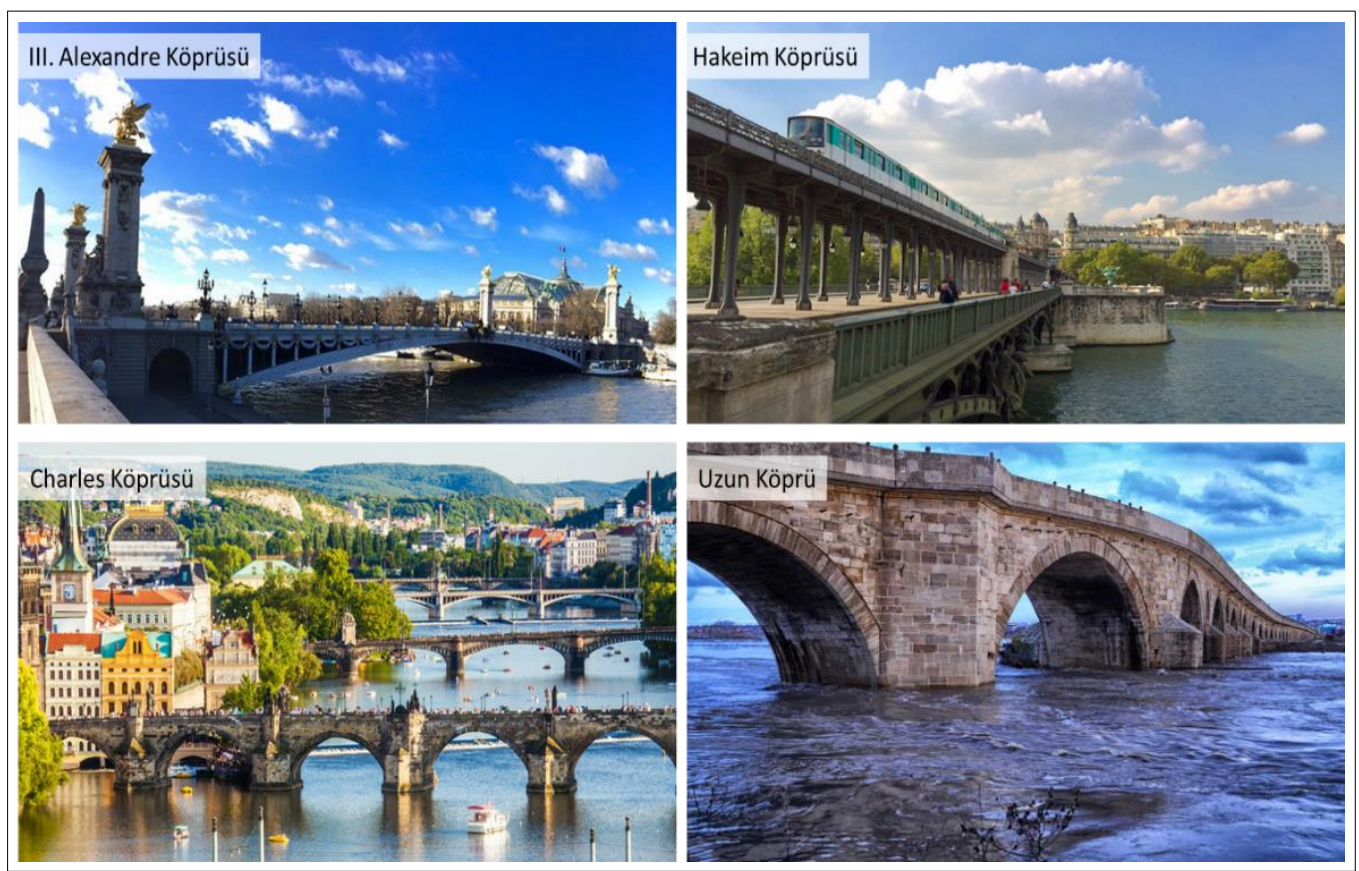

Şekil 1. Paris, Floransa ve Prag kent kesitlerinde yer alan köprü örnekleri (III. Alexandre Köprüsü, 2021; Hakeim Köprüsü, 2021; Charles Köprüsü, 2021; Uzun Köprü, 2021)

Kent günlüğü kullanıcıların kent yaşamını algılamasını sağlamaktadır. Kent günlüğü sayesinde kenti anlamak, keşfetmek ve kentsel peyzajları kavramak kolaylaşmaktadır (Sağlık, 2020). Kent günlüğünün değerlendirilmesi ile kentsel peyzajı etkileyen kent bileşenleri okunabilmektedir (Karagüler ve Korgavuş, 2014). Çanakkale kent günlüğünde ise geçiş mekânları önemli yer tutmaktadır. Her yaştan ve gruptan kentlinin kullandığı bu mekânların, araştırmacı tarafından çeşitli kavramlar ekseninde okuması yapılmıştır.

Çalışma kapsamında kentin simgesi haline gelen Çanakkale ili Sarıçay Nehri ve buna bağlı araç trafiğine ve yaya kullanımına açık olan toplam 6 köprü ele alınmıştır. Çanakkale ilinin kent günlüğünde en önemli imaj ögesi niteliği taşıyan Sarıçay Nehri, kent kimliğinin en önemli belirleyici ögelerindendir.

Yerinde gözlem sonucu tespit edilen veriler ışığında detaylı literatür taraması yapılmıştır. Sarıçay Nehri'nde bulunan yaya ve taşıt kullanımına açık olan köprüler ele alınarak bu alanların kent günlüğünde yansımaları yorumlanmıştır.

\section{Materyal ve Yöntem}

\subsection{Materyal}

Kentin konumsal ve meteorolojik nitelikleri aşağıda sunulduğu gibidir.

- Çanakkale ili Marmara Bölgesi'nin güneyinde, Türkiye'nin ise kuzeybatısında konumlanmıştır. Ege ve Marmara Bölgesi kesimleri arasında yer alır (Şekil 2). III, 12 ilçeden oluşmaktadır. Kentin genel nüfus değeri 2020 yılı verilerine göre 541.548 kişi olup merkez ilçe nüfusu 184.184'tür (Çanakkale Nüfusu, 2021). Edirne, Tekirdağ ve Balıkesir kenti çevreleyen komşu illerdir.

- Çanakkale kentinde geçiş iklimi görülmekle birlikte Akdeniz iklimi özellikleri saptanır. Genel olarak kış aylarındaki sıcaklık ortalaması düşüktür. En düşük sıcaklık $\left(-11,5^{\circ} \mathrm{C}\right)$ şubat ayında; en yüksek sıcaklık $\left(39,1^{\circ} \mathrm{C}\right)$ ile ağustos ayında görülmektedir. Güneybatı yönlü Lodos rüzgârı (ortalama değer; $34,0 \mathrm{~m} / \mathrm{sn}$ ) kent genelinde hâkim olmaktadır (Meteoroloji Genel Müdürlüğü, 2021).

Sarıçay, Çanakkale ilinin önemli akarsularındandır ve kent merkezini ikiye bölmektedir (Odabaşı, 2005). Sarıçay'ın kaynağı, Çanakkale il merkezinin doğusunda bulunan plato alanıdır. Koca Çay olarak da bilinen Sarıçay Nehri yaklaşık olarak $40 \mathrm{~km}$ uzunluğundadır ve ilin kuzeyinde bulunan Çimenlik Kalesi'nden boğaza dökülür. Sarıçay Nehri üzerinde kentin su ihtiyacını karşılayan Atikhisar barajı bulunur (Gürkan, 2005). Çanakkale sınırları içerisinde bulunan Sarıçay Nehri (Atikhisar Vadisi) sahip olduğu biyolojik çeşitliliklerle de öne çıkmaktadır. Şehrin günlük su ve tarımsal sulama kullanımını 
karşılayan Sarıçay Nehri, Atikhisar Barajı́nın su toplama havzası olarak nitelendirilmektedir (Gürbüz, 2019).

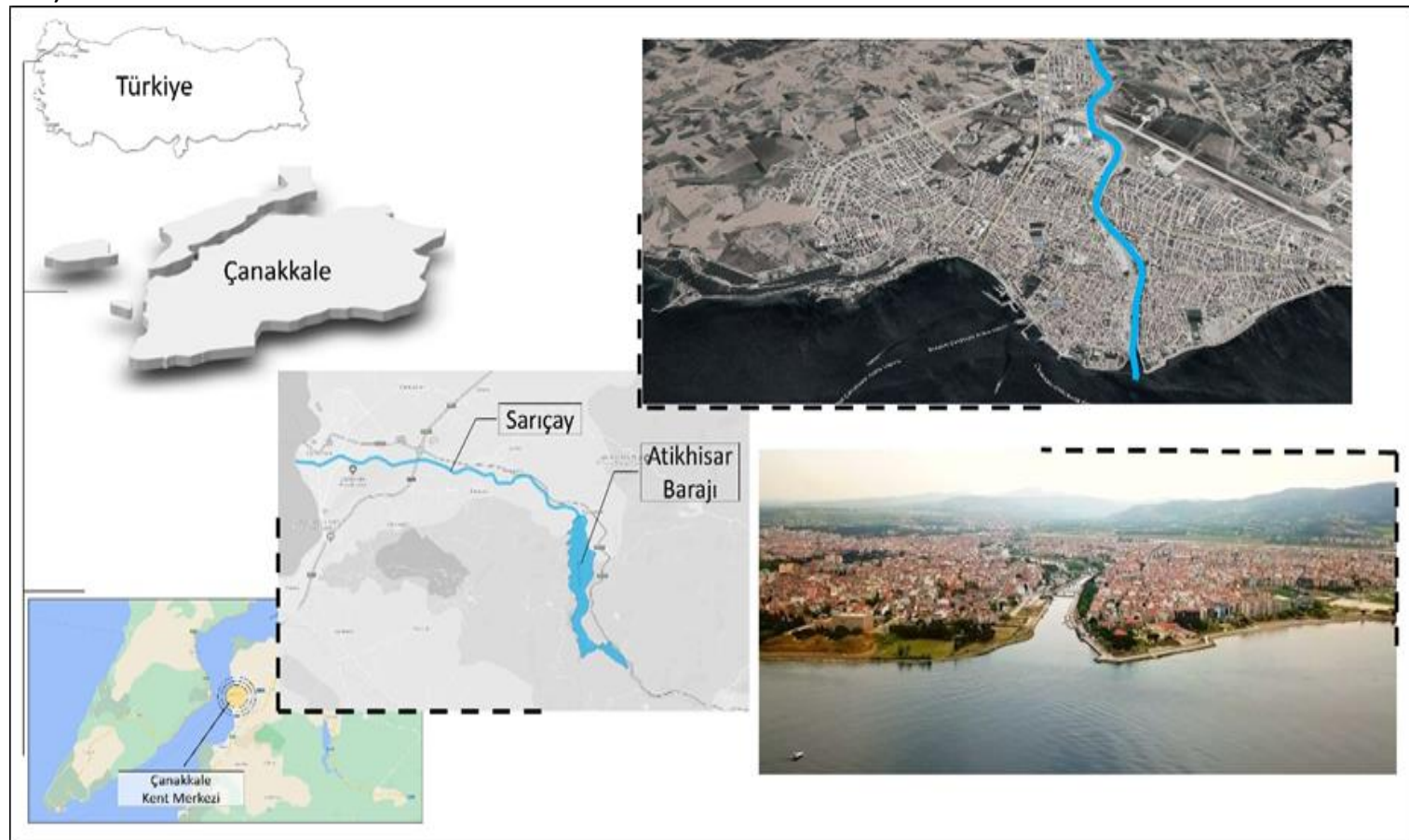

Şekil 2. Çalışma alanın konumu (Türkiye Dilsiz Haritası; Çanakkale Dilsiz Haritası; Google Earth'den faydalanarak yazar tarafından değiştirilerek hazırlanmıştır.)

Sarıçay Nehri, kentin coğrafi yapısı ile varlığını gösteren ayrıca kenti şekillendiren, kent merkezinde etkisi ve seyri devam eden nehirin yakın çevresinde dinlenme, eğlenme, rekreasyonel etkinlikleri gerçekleştirmek için yapılacak mekânsal kompozisyonlarla desteklenmesi gereken önemli bir kentsel ögedir (Sağlık ve diğerleri, 2021).

Kentin konum ve meteorolojik nitelikleri dışında önemli ve doğal bileşenlerinden olan Sarıçay Nehri ile bağlantılı köprüler çalışmanın materyalini oluşturmaktadır.

Kenti fiziksel, ekonomik ve sosyal boyutu ile etkileyen köprüler; Sarıçay Nehri üzerinde bulunan, taşıt ve yaya kullanımının birlikte olduğu Troya Köprüsü, Atatürk Köprüsü, İnönü Köprüsü ile sadece yaya kullanımına açık 3 köprü olmak üzere toplamda 6 köprü olarak çalışma kapsamında ele alınmıştır.

\subsection{Yöntem}

Geçiş mekânlarının niteliğini, işlevsel kullanımını ve kent içi durumu değerlendirmek için çalışmada Velioğlu (1996) tarafından geliştirilen yöntem yaklaşımı kullanılmıştır. Mimarlık eğitiminde kullanılan çözümleme yöntemi, bu çalışmada; geçiş mekânlarının kent içindeki durumunu değerlendirmek için referans alınmıştır. Söz konusu çözümleme yöntemi; hareket, mekân ve kullanım durumlarının birlikte değerlendirildiği örtüşük formülasyonudur. Formülasyon kentin herhangi bir bileşenine yönelik kullanılabilecek nitelik ve kapsamdadır. Bileşenin türüne göre çözümleme yapılan değerler farklılık gösterebilmektedir (Velioğlu, 2002). Formülasyon dahilinde yapılan çözümlemede;

- Hareket kavramı ekseninde yaya ve araç sirkülasyonu ile ilgili veriler;

- Mekân kavramı ekseninde çevre ile ilişkili biçim, boyut, oran ve doku katmanı ile ilgili veriler;

- Kullanım kavramı ekseninde ise kullanımın çeşitliliği, işlevselliği ve kullanıcı kitlesi ile ilgili verilere ulaşılmaktadır.

Bu bağlamda Çanakkale kent merkezinde bulunan Sarıçay Nehri üzerinde konumlanmış, kent merkezinin iki bölgesini birbirine bağlayan geçiş mekânlarının (Troya Köprüsü, Atatürk Köprüsü, İnönü Köprüsü, Halk Köprüsü, Tahta Köprü) üçlü örtüşük formülasyon yöntem yaklaşımı ile durum değerlendirmesi yapılmıştır. 
Araştırma dahilinde yerinde gözlem ve analizlerle beraber detaylı literatür taraması yapılmıştır. Çalışma konusu ve kapsamı belirlenerek alan analizi yapılmış ve fotoğrafları çekilmiştir. Köprüler kategorize edilerek kent günlüğündeki etkisi bağlamında analiz ve gözlemleri gerçekleştirilmiştir. Çalışma alanlarının mevcut durumu hakkında bilgiler verilerek geçiş mekânlarının kent içindeki durumu değerlendirilmiştir.

\section{Bulgular}

Çalışma alanı olarak Çanakkale kent günlüğünde odak noktalarından olan Sarıçay Nehri ve buna bağlı araç ve yaya erişimine açık 3 köprü (Troya Köprüsü, Atatürk Köprüsü ve İnönü Köprüsü) ve sadece yaya kullanımına açık 3 köprü olmak üzere toplamda 6 köprü ele alınmıştır. Şekil 3'te gösterildiği gibi A1-B1C1 sembolleri yaya ve araç trafiğine açık köprüleri, A2-B2-C2 sembolleri ise sadece yaya kullanımına açık köprüleri simgelemektedir.

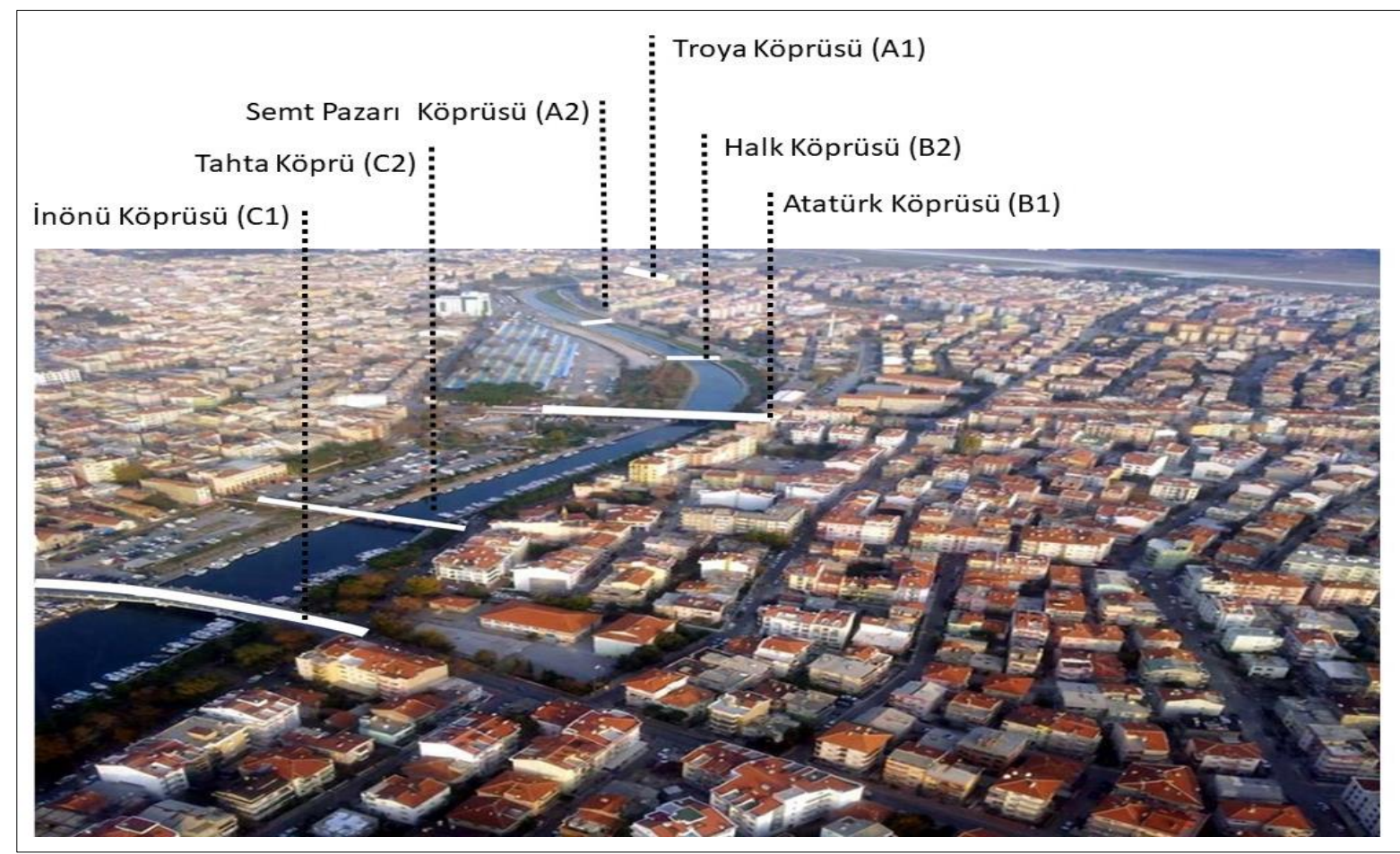

Şekil 3. Çalışma alanındaki köprülerin konumu (Sarıçay Nehrinin havadan görünümü, 2021).

\subsection{Yaya ve Taşıt Trafiğine Açık Geçiş Mekânları}

Sarıçay Nehri üzerinde yaya ve taşıt trafiğine açık geçiş mekânı niteliği taşıyan köprüler Troya, Atatürk ve İnönü Köprüsü’dür.

\subsubsection{Troya Köprüsü (A1)}

Köprü ve üzerinde bulunduğu Troya Caddesi karşııılı etkileşim halindedir. Kent içi yoğun trafiğin gerçekleştiği ikincil derece kullanım aksı üzerinde bulunmaktadır. Sarıçay Nehri üzerinde bulunan Troya Köprüsü diğer köprülere göre deniz çizgisine konum olarak daha uzakta yer almaktadır.

Hareket kavramı üzerinden köprü incelendiğinde;

- Yürünebilirlik bağlamında köprü üzerinde yayalar için kaldırım bulunmakta olup; bisiklet kullanıcıları için "kent içi bisiklet rotası" dahilinde oluşturulan araç yolu ile aynı kotta bisiklet yolu yer almaktadır. " Erişilebilirlik yaya, bisiklet ve araç akış ve gelişlerine göre biçimlenmiştir. • Kentin diğer önemli sirkülasyon aksları ile bağlantılı olarak kurgulanmıştır.

Mekân kavramı üzerinden köprü incelendiğinde;

- Uzunluğu 124 metre olan köprünün taşıt yolu asfalt kaplamadır. Refüj ile bölünmüş 2 gidiş 2 geliş toplam 4 şeritten oluşmaktadır. Köprünün kullanım alanının genişliği refüj dahil ortalama 30 metredir (Şekil 4). - Bisiklet yolu için zeminde mavi renklendirme ile vurgulama yapılmış olması algılanabilirliği 
kolaylaştırmaktadır. - Köprünün başlangıç ve bitiş noktaları okunabilir niteliktedir. • Kentte çoğunlukla taşıt trafiği ile ön plana çıkmaktadır.

Kullanım kavramı üzerinden köprü incelendiğinde;

- Köprünün yakın çevresinde yer alan kentsel mekânlarda tasarımsal çözümler mevcuttur. • Köprü üzerinden kente bakıldığında sergilenen manzaralar olumludur. • Köprünün altında bulunan açık alan rekreasyonel tasarım alanı olarak kentlinin kullanımına sunulmuştur. - Gece - gündüz kullanım durumunda süreklilik sağlanmaktadır. - Aydınlatma armatürleri ve köprü korkulukları güvenlik açısından olumludur. - Çalışmanın diğer materyalleri olan geçiş mekânları bu köprünün sergilediği panorama kapsamında bulunmamaktadır.

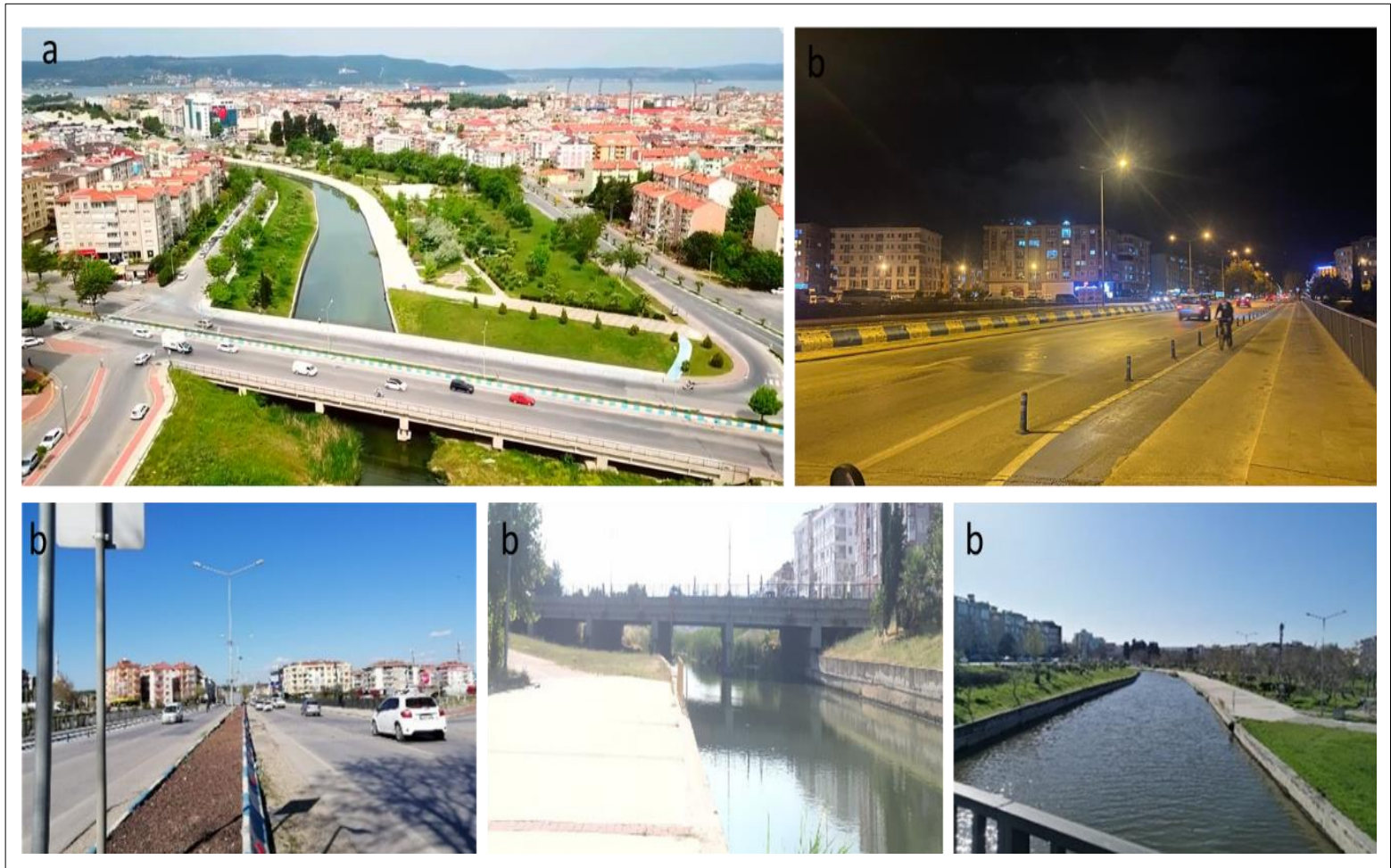

Şekil 4. Troya Köprüsü genel profili ve köprüden kesitler (a: Öztürk, 2020; b: Orijinal, 2021).

\subsubsection{Atatürk Köprüsü (B1)}

Kentsel dokuda önemli yeri olan Atatürk köprüsü, kentli tarafından dış mekân yaşantısına dahil edilen bir geçiş mekânıdır. 1940'lı yıllarda temelleri atılan Atatürk Köprüsü, kentin iki yakası arasında ulaşımı sağlamaktadır. 1948-1949 yıllarında ahşap materyalden oluşan bu köprüyü çoğunlukla yayalar kullanmıştır. 1950'li yılların sonunda ise köprünün revizesi yapılmış olup beton malzeme kullanımı ile yenilenmiştir (Öncü, 2016). Köprünün uzunluğu yaklaşık 170 metre, genişliği ise yaya yolu dâhil ortalama 20 metredir (Şekil 5).

Hareket kavramı üzerinden köprü incelendiğinde;

- Erişilebilirlik yaya, taşıt akış ve gelişlerine göre biçimlenmiştir. - Taşıt trafiği ile yaya trafiği kesişmemekte birbirine destek olmaktadır. - Yayalar için yürünebilirliği destekleyen kaldırım mevcuttur. Ancak köprü üzerinde hareket eden insan varlığı ve araç yoğunluğundan dolayı zayıf kalmaktadır. - Yaya ve taşıtların geliş odaklarına göre diğer kentsel alanlar ile bağlantıııdır.

Mekân kavramı üzerinden köprü incelendiğinde;

- Yaya yolu siyah bazalt ve andezit plak taş malzeme; araç trafiğinin gerçekleştiği yolda ise asfalt malzeme kullanılmıştır. • 7 Aralık 2013'te yenilenen köprüde modern aydınlatma armatürlerine yer verilmiştir. Köprünün dışı ahşap görünümlü kompozit panelle kaplıdır (Çanakkale Atatürk Köprüsü, 2013). - Hem araç hem de yaya trafiğini nedeniyle oluşan karmaşa kentliyi olumsuz etkileyebilmektedir. Yaya yolu ile taşıt yolu arasında sınırlayıcı/engelleyici herhangi bir donatı bulunmamaktadır. Bu durum, kentliye mekân duygusunu unutturma potansiyeli taşımaktadır. - Köprünün mekânsal kimliği, kent 
günlüğünde yoğun kullanım durumu nedeniyle ortaya çıkmaktadır. - Köprünün başlangıç ve bitiş noktalarının algılanabilir ve okunaklı olması herkes için kullanımı kolaylaştırmaktadır.

Kullanım kavramı üzerinden köprü incelendiğinde;

- Köprünün yakın çevresinde tasarımsal çözümler kısmen mevcuttur. Köprü üzerinden alt kotlara bakıldığında görünen kentsel açık alanlar görsel nitelik bakımından olumludur. - Gece - gündüz kullanımda sürekliliğe imkân vermektedir. - Aydınlatma armatürleri ve köprü korkulukları mekân güvenliği açısından olumlu özellik göstermektedir. - Köprünün görsel açıdan sunduğu kentsel manzaralar ferahlık ve canlılık duygusunu pekiştirmektedir. - Atatürk Köprüsü’nün panoramasında Troya Köprüsü görünmemekte; İnönü Köprüsü ve Tahta Köprü siluetleri görünmektedir (Şekil 5).

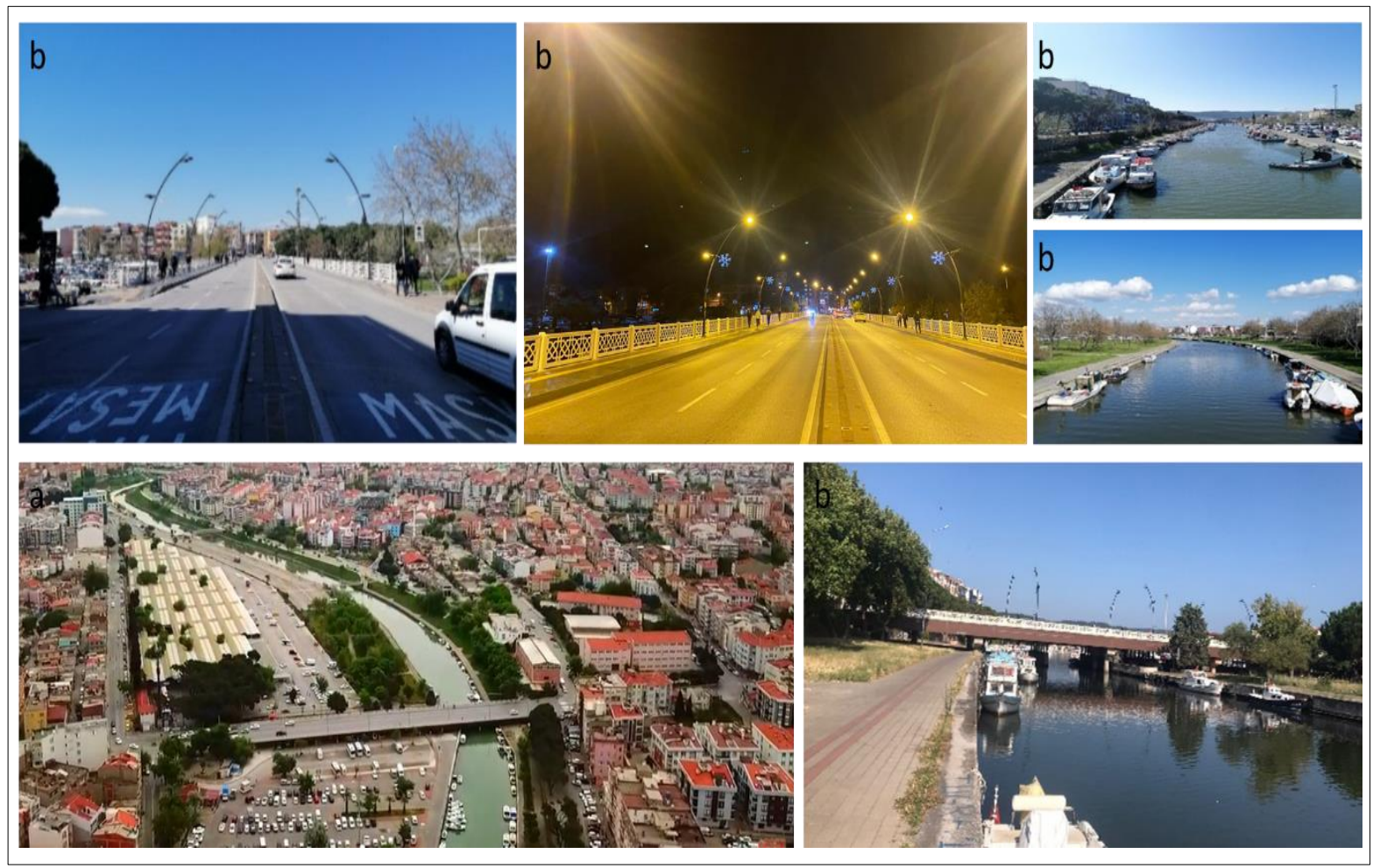

Şekil 5. Atatürk Köprüsü genel profili ve köprüden kesitler (a: Öztürk, 2020; b: Orijinal, 2021).

\subsection{3. İnönü Köprüsü (C1)}

Köprü kentin günlüğünde diğer geçiş mekânlarına göre estetik değeri yüksek, kent içi ulaşımda önemli rolü olan bir köprüdür (Şekil 6). Kentlinin kullanımına 2012 yılında sunulmuştur (İnönü Köprüsü, 2012). Gün geçtikçe kullanım sıklığı ve yoğunluğu artış göstermektedir. Alternatif ulaşım ağı gibi düşünülmüş olsa da artan taşıt trafiği sonucunda ana ulaşım aksı olarak değerlendirmek mümkündür.

Hareket kavramı üzerinden köprü incelendiğinde;

- Yürünebilirlik bağlamında köprü üzerinde yayalar için kaldırım bulunmaktadır. - Bisiklet kullanıcıları için "kent içi bisiklet rotası" kapsamında araç yolu ile aynı kotta bisiklet yolu yer almaktadır. Erişilebilirlik yaya, bisiklet ve araç akış ve gelişlerine göre biçimlenmiştir. • Kentin diğer önemli sirkülasyon aksları ile bağlantılı olarak kurgulanmıştır. - Köprü bağlantılı olduğu alanlara yönlendirme konusunda olumludur. - Köprü üzerinde yaya, taşıt ve bisiklet kullanımı oldukça fazladır. - Yaya erişimi ve yol niteliği yüksektir.

Mekân kavramı üzerinden köprü incelendiğinde;

- Uzunluğu 115 metre olan köprünün taşıt yolu asfalt kaplamadır. 1 gidiş 1 geliş toplam 2 şeritten oluşan köprüde refüj bulunmamaktadır. Köprünün kullanım alanının genişliği yaklaşık 15 metredir. Bisiklet yolu için zeminde mavi renklendirme ile vurgulama yapılmış olması algılanabilirliği kolaylaştırmaktadır. - İnönü Köprüsü'nün dış cephesi mermer taşlarla kaplıdır • Köprünün başlangıç ve bitiş noktaları okunabilir niteliktedir. - Köprüde; deniz, rüzgâr, balık ve balıkçı temalarını vurgulayan 
heykeller bulunmaktadır. Bu nedenle estetik açıdan olumlu imaj sunan köprünün kimliği desteklenmektedir.

Kullanım kavramı üzerinden köprü incelendiğinde;

- Köprünün yakın çevresi rekreasyonel ihtiyaçlara çözüm sunan tasarımlar ile desteklenmiştir. - Gecegündüz kullanım durumunda sürekliliği devam etmektedir. - Yayalar için güvenlik unsuru araç ve yaya yolu arasında bulunan bariyer ile sağlanmaktadır. - Taşıt yolu ile aynı kotta bulunan bisiklet yolu bariyer ile sınırlandırılarak bisikletlinin güvenliği desteklenmiştir. - Köprü üzerinden kente bakıldığında ortaya çıkan sahneler olumlu etki bırakmaktadır. - Konumu itibari ile nehrin denizle buluştuğu noktaya en yakın olan köprüdür. Dolayısıyla köprünün manzarası Çanakkale Boğazı'na açılan panoramadan oluşmaktadır.

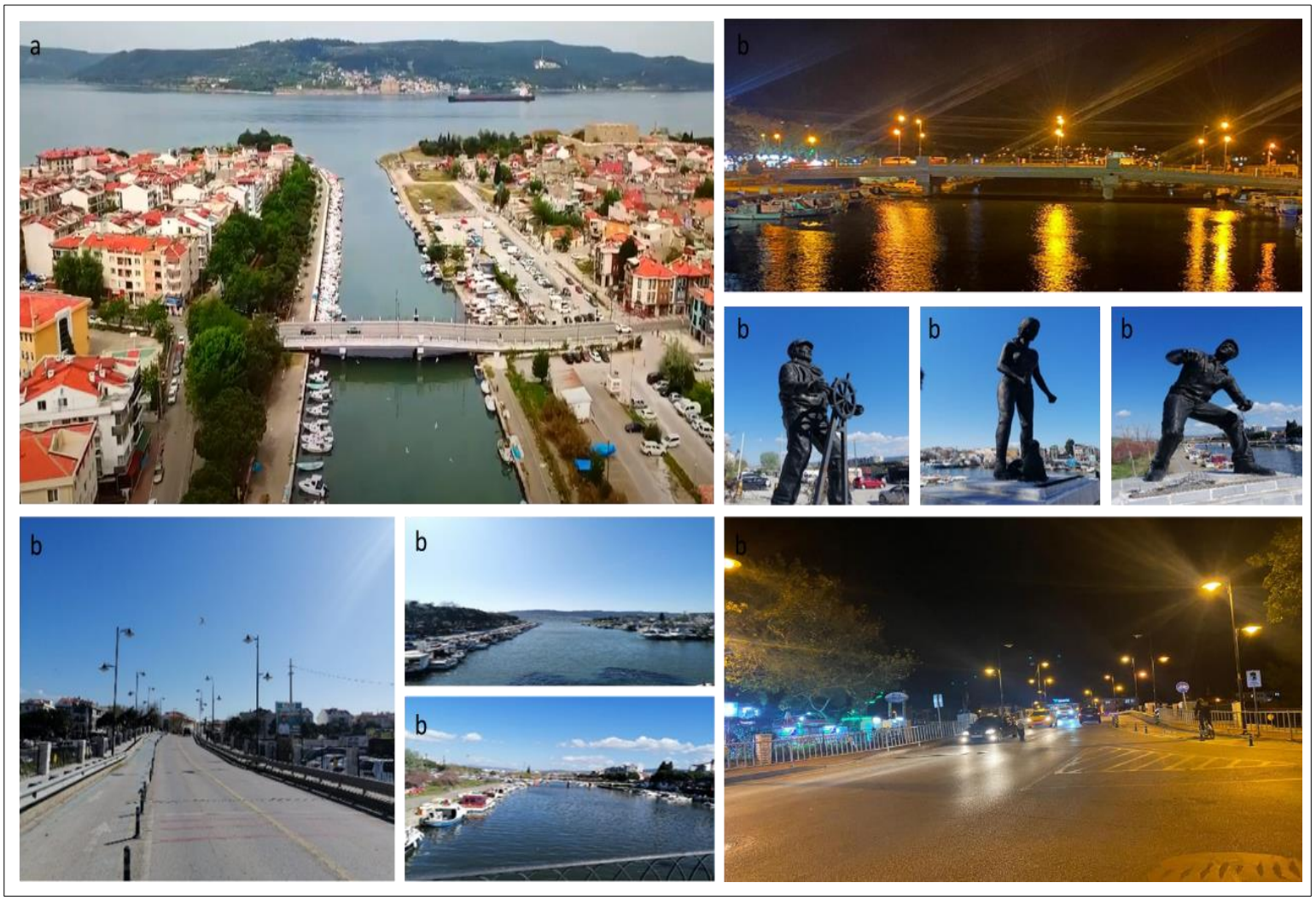

Şekil 6. İnönü Köprüsü genel profili ve köprüden kesitler (a: Öztürk, 2020; b: Orijinal, 2021).

\subsection{Yaya Kullanımlı Geçiş Mekânları}

Sarıçay Nehri üzerinde yaya kullanımına açık geçiş mekânı niteliği olan 3 adet köprü vardır. Bunlar (A2) Semt Pazarı Köprüsü; (B2) Halk Köprüsü; (C2) Tahta Köprüdür. Yaya kullanımlı geçiş mekânlarının hareket, mekân ve kullanım kavramlarına yönelik değerlendirmesi aşağıda sunulduğu şekildedir.

Hareket kavramı üzerinden yaya kullanımlı geçiş mekânları incelendiğinde;

Semt Pazarı Köprüsü (A2): - Yürünebilirlik anlamında konforlu ortam oluşturmaktadır. - Semt pazarının kurulduğu günlerde köprü üzerinde kentli yoğunluğu artış göstermektedir (Şekil 7).

Halk Köprüsü (B2): - Yayalar için yürünebilirlik konforludur. - Kent merkezinin en önemli alt bölgelerinden olan semt pazarına erişim için kentli tarafından oldukça fazla kullanılmaktadır (Şekil 8).

Tahta Köprü (C2): - Yayalar için yürünebilirlik değeri güçlüdür. - Köprü üzerinde yaya hareketi oldukça yoğundur. - Kent merkezinde doğu-batı yönlü olarak erişimde bu köprü, kesintiye uğramadan sürekliliği sağlamaktadır (Şekil 9). 


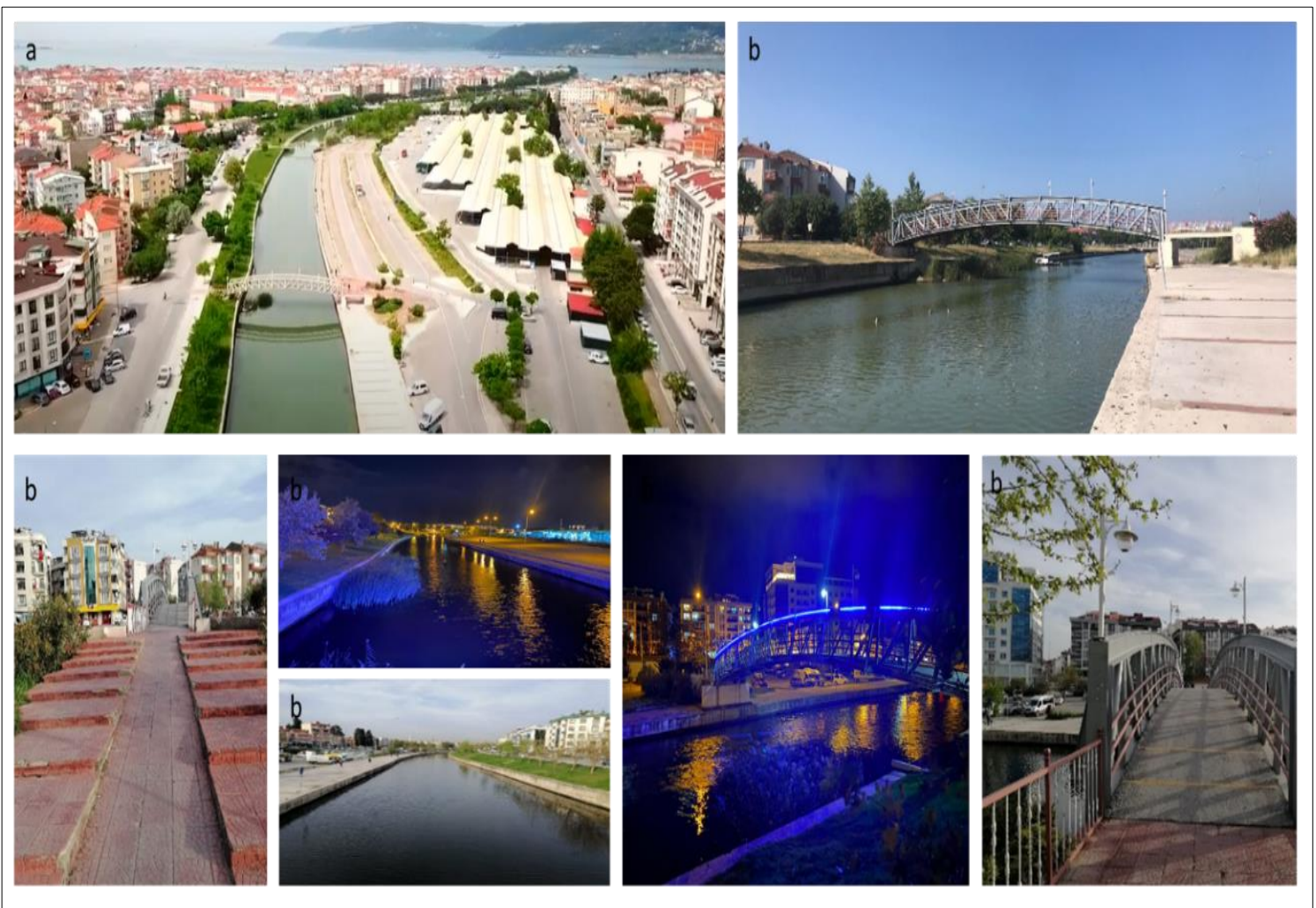

Şekil 7. Semt Pazarı Köprüsü genel profili ve köprüden kesitler (a: Öztürk, 2020; b: Orijinal, 2021).

Mekân kavramı üzerinden yaya kullanımlı geçiş mekânları incelendiğinde;

Semt Pazarı Köprüsü (A2): - Yaya köprüleri içinde en son yapılan akstır. - Uzunluğu 45 metre ve genişliği 4 metredir. - Asfalt uygulaması zemin kaplamada kullanılmıştır. - Merdiven ve rampanın kombinasyonu ile köprüye erişim sağlanmaktadır. - Merdiven ve rampanın zemin kaplaması kırmızı renkli granit ile kaplanarak farkındalık oluşturulmuştur (Şekil 7).

Halk Köprüsü (B2): - Köprünün uzunluğu 32 metre genişliği ise 3 metredir. - Zemin kaplaması olarak metal döşeme elemanı kullanıımıştır. • Köprüye yürüyüş yolundan rampa ve merdiven kullanılmaksızın doğrudan erişim sağlanmaktadır (Şekil 8).

Tahta Köprü (C2): • Köprünün uzunluğu 110 metre, genişliği ise 5 metredir. • Zemin kaplamasında ahşap ve bazalt küp taş tercih edilmiştir. - Köprüye erişim rampa ve merdivenlerle sağlanmaktadır. • Köprünün başlangıç ve bitiş noktaları kentliyi yönlendirici niteliktedir (Şekil 9). 

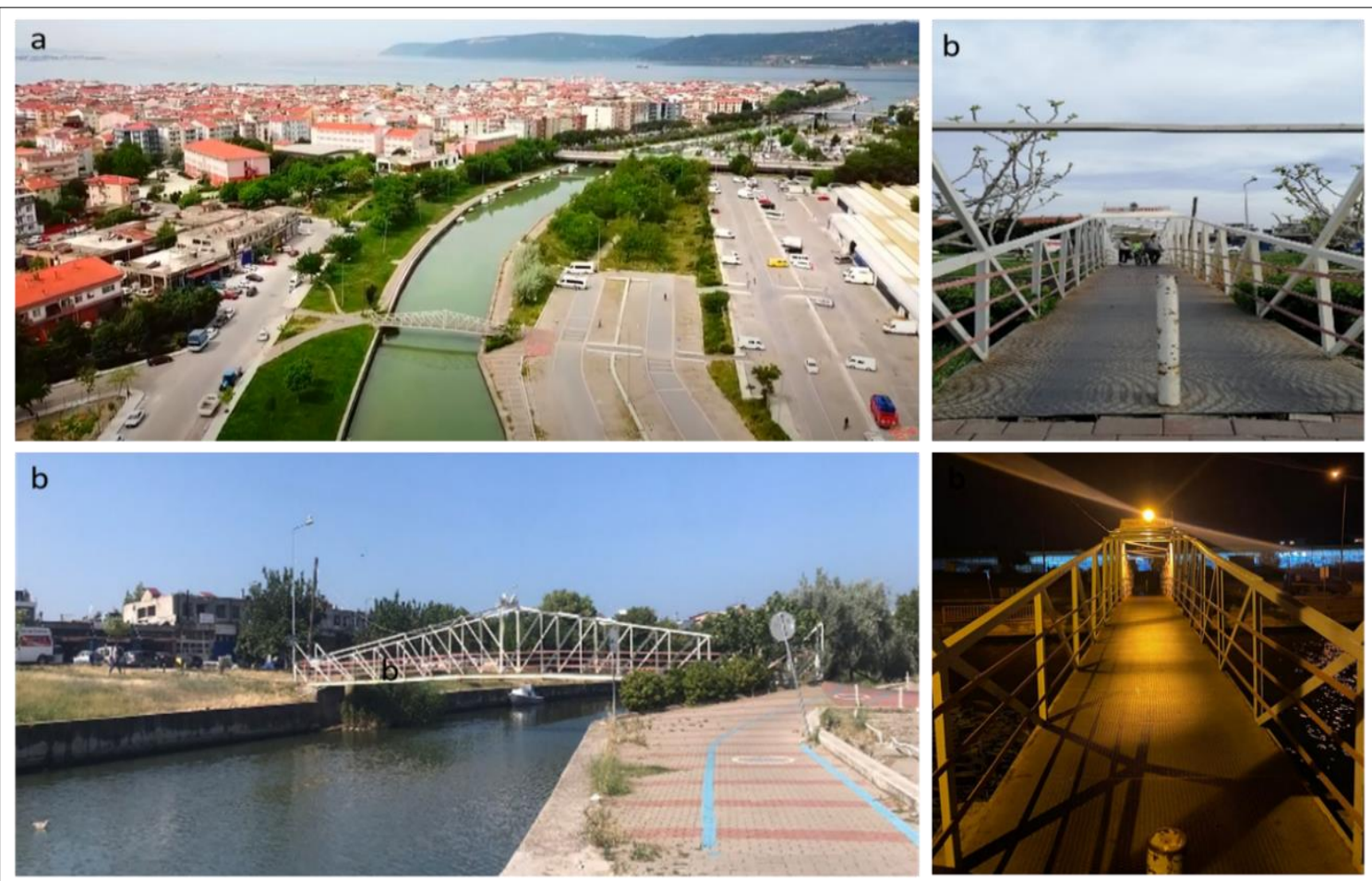

Şekil 8. Halk Köprüsü genel profili ve köprüden kesitler (a: Öztürk, 2020; b: Orijinal, 2021).

Kullanım kavramı üzerinden yaya kullanımlı geçiş mekânları incelendiğinde;

Semt Pazarı Köprüsü (A2): - Semt pazarının varlığı bu köprünün yapılması gerekliliğini ortaya çıkarmıştır. Dolayısıyla köprünün yakın çevresinde semt pazarı ve yerleşim bölgeleri bulunmaktadır. • Güvenlik kriteri köprü korkulukları ile sağlanmıştır. - Köprü kullanımı sırasında canlılık, hareketlik ve koşturmaca bir ortam oluşmaktadır. - Gece-gündüz kullanımı açısından kent günlüğünde yerini korumaktadır. - Köprü üzerinden bakınca oluşan görsel kesit kentsel dokunun dikey yapılarını ve Sarıçay rekreasyonel alanını kapsamaktadır (Şekil 7).

Halk Köprüsü (B2): - Yakın çevresinde en önemli öge semt pazarıdır. Semt pazarının kurulmadığı günlerde pazar alanı ve bu köprü kentli için önemli bir sirkülasyon kaynağı olarak tercih edilmektedir. - Köprü korkulukları ile güvenlik sağlanmaktadır. - Gece-gündüz kullanımında sürekliliği görmek mümkünüdür. - Herkes için tasarım olgusunda yeterli değildir. - Görsel nitelik açısından zayıftır. Köprünün panoraması daha çok kentsel yapılardan oluşmaktadır (Şekil 8).

Tahta Köprü (C2): - Yakın çevresinde taşıt yolu bulunmakta ve geçiş mekânı kullanılarak kentli, bu yollardan ayrışmaktadır. - Gece- gündüz kullanımında süreklilik sağlanmaktadır. • Köprüde olumlu yaya deneyimi gerçekleşerek hedefe ulaşmak mümkündür. - Güvenlik köprü korkulukları ile sağlanmıştır. • Köprü kullanımında ferahlık ve canlılık hissi oluşması muhtemeldir. - Görsel nitelik açısından köprünün manzarası su, balıkçı tekneleri ve yeşil ögelerden oluşmaktadır. - Tahta Köprü'den İönü ve Atatürk Köprüsü’nün siluetleri görünmektedir (Şekil 9). 


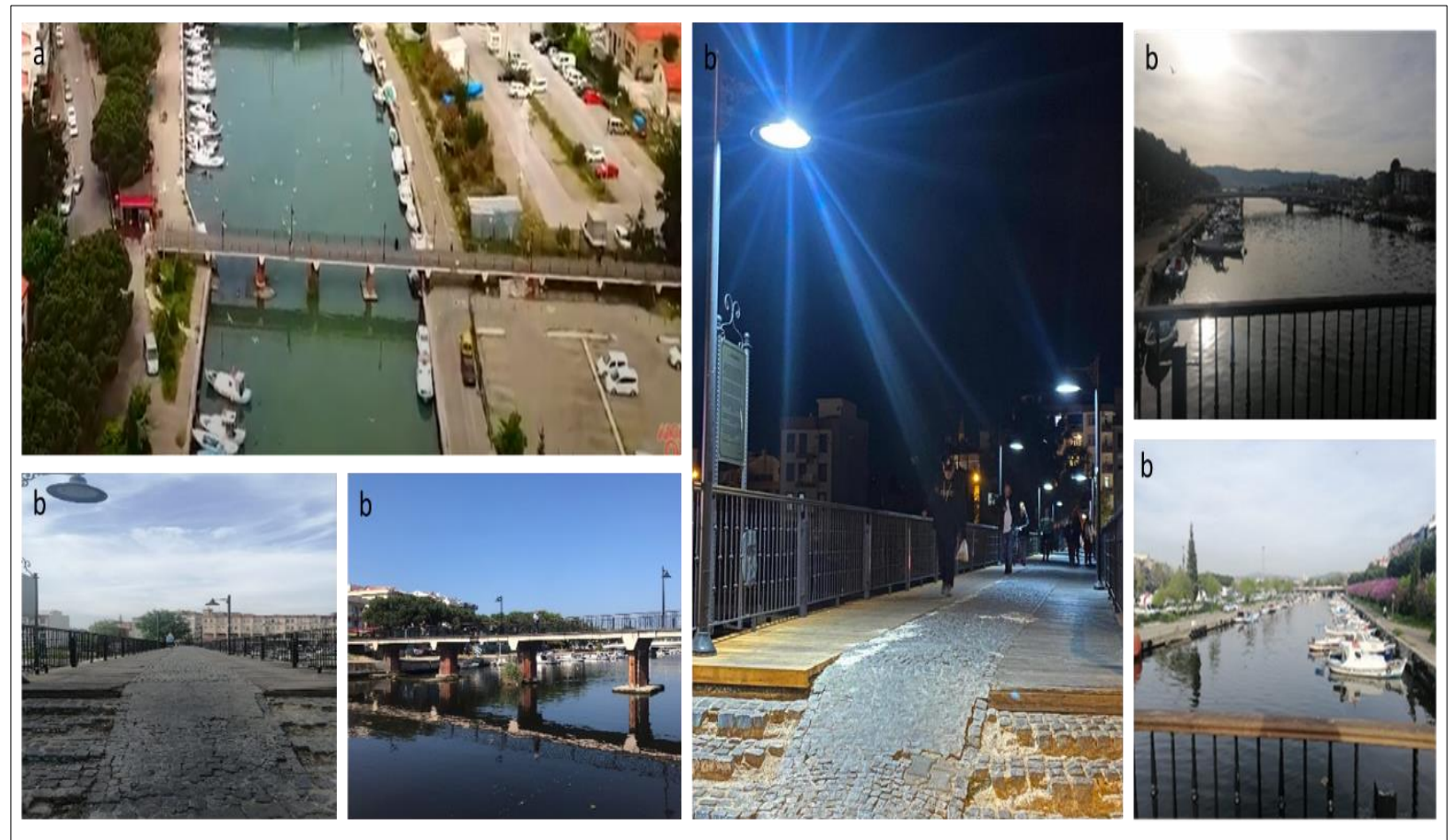

Şekil 9. Tahta Köprü genel profili ve köprüden kesitler (a: Öztürk, 2020; b: Orijinal, 2021).

\section{Tartışma ve Sonuç}

İki alan arasında geçişi sağlayan mekânlar geçiş mekânları olarak tanımlanabilmektedir. Söz konusu mekânlar kentsel dokuda sürekliliği ve bütünlüğü sağlayan önemli kent bileşenleridir (Dizman, 2015). İçinde su ögesi bulunan kentlerin ayrılmaz bir parçası olan köprüler, bu çalışmada geçiş mekânları olarak nitelenmiştir. Üçlü örtüşük formulasyon kapsamında; Çanakkale kentinin ana bölgelerini bir arada tutan geçiş mekânları incelenmiş; hareket, mekân ve kullanım kavramları ekseninde değerlendirme yapılmıştır. İnceleme ve değerlendirme aşamaları geçiş mekanlarının kentin günlüğünde okunmasını sağlamıştır.

Kent içinde, gündelik yaşamın aktığı rotalar üzerinde bulunan geçiş mekânları hem yaya hareketinden hem de taşıt trafiğinden oluşmaktadır. Yoğun kent dokusunda, yaya odaklı düşünülerek yapılan Semt Pazarı Köprüsü, Halk Köprüsü ve Tahta Köprü isimli geçiş mekânlarının hareket, mekân ve kullanım değeri incelendiğinde; bu mekânların zorunlu yaya hareketi sergilediği gösterilmiştir. Rutin ve tekrarlı günlük gereklilikleri kapsayan, bir yerden bir yere giderken zorunlu yürüme eylemi gerçekleşmektedir. Yaya hareketini oluşturan fonksiyonu ile ön plana çıkan geçiş mekânları gece-gündüz kullanımda süreklilik göstermekte, olumlu deneyim sunmakta ve hedefe ulaşma amacında yayayı desteklemektedir.

Troya, Atatürk ve İnönü köprüleri ise taşıtların kontrollü dolaşımı ile yaya yoğunluğu ve hareketinin birlikte kurgulandığı geçiş mekânlarıdır. Söz konusu mekânlarda; gece-gündüz kullanımı sürekliliği ile taşıt ve yaya olarak kamusal birikme olgusu gözlemlenmiştir. Bu birikim yıl boyunca yerli yabancı turist ziyaretleri ile artma yönünde değişim göstermektedir.

Köprüye yönelim ve köprüden ayrılma kriteri, erişilebilirlik, ulaşılabilirlik ve yürünebilirlik kavramları ile doğrudan bağlantılıdır. Yang ve Huang (1997)'ın yaptıkları çalışmada kent içi köprülerin modellenmesinde etkili olan faktörler fonksiyonel, işlevsel, görsel ve yapısal özellikler olarak sıralanmıştır. Köprünün düzlem bileşiminin, işlevsel nitelikleri ve çevresel bağlantılar ile uyumlu olması gerektiği vurgulanmıştır. Köprünün kot tasarımının görsel kompozisyonu ortaya çıkaran unsur olarak önem taşıdığı ifade edilmiştir. Bu bağlamda Çanakkale Sarıçay Nehri üzerinde konumlanmış olan geçiş mekanlarının fonskiyonel, işlevsel, görsel ve yapısal özellikler bakımından örtüştüğünü ifade etmek mümkündür.

Ertaş (2011), Osmanlı yollarının temel unsurlarını ortaya koymayı amaçladığı çalışmada; Evliya Çelebi nehir üzerinde yapılmış bir geçit olmanın ötesinde anlamlar yüklediği köprüleri, seyrine doyum 
olmayan sanat ve mühendislik harikası yapılar olarak tanımlamıştır. Bu tanımdan hareketle Çanakkale kent içi köprüleri (geçiş mekanları) geçit fonksiyonunu yerine getiren kent ögesi olmanın ötesine geçememiştir. Mekanların işlevsel açıdan kentin günlüğünde önemli rol oynadığı, kent içi ulaşım sisteminin ayrılmaz parçası olduğu hatta bu geçiş mekânları sayesinde ulaşım sisteminin oluştuğunu söylemek mümkündür.

Kaya (2005), çalışmasında köprüyü kentin görüntü kavramı olarak tanımlamıştır. Bu tanımla köprünün kendisine, kente eklemlenmesiyle birlikte değişen kentin görselliğine odaklanmıştır. İçinden su geçen kentlerde görüntüsel arkeolojinin okunmasında köprülerin rol kazandığını ortaya koymuştur. Dolayısıyla Çanakkale kenti Sarıçay Nehri köprüleri, nehrin yakın çevresinde gelişen ve değişen yapısal bitkisel görüntünün okunması açısından bir kentsel bileşen olarak rol üstlenmektedir.

Çanakkale'de geçiş mekanlarının, çalışmanın giriş bölümünde aktarılan Avrupa'dan ve ülkemizden örneklere bakıldığı zaman kentin kimliğine ya da tarihi dokusuna katkı sunmadığı gözlemlenmiştir. Sarıçay Nehri üzerinde olan köprüler hareket, mekân ve kullanım gibi kavramlara vurgu yapsa da geçiş mekanları kentin ulaşım ihtiyacını karşılayan unsur olmaktan çıkamamış, kent imgeleri arasında yerini alamamıştır. Arslan (2020), kent içi köprüleri yaya ve taşıt kullanımı olarak fonksiyon çeşidi, ikonik özellikleri, yapısal özellikleri ve tasarım ilkeleri kapsamında incelemiştir. Yapının uzunluğu, deniz ve nehir arasından geçişi sağlaması, malzeme çeşidi, geometrik form yaklaşımı ile ikonik özellikleri belirlenerek Büyükçekmece Köprüsü’nü; uzunluğu, eşsiz form ve renk unsuru ile estetik değeri güçlü olan Golden Gate köprüsünü; yüksek teknolojik çelik malzeme ve transparan cephe tasarımı ile ön plana çıkan Millau Viaduct köprüsünü; eşsiz yapım stili, yenilikçi malzeme çelik konstrüksiyon kullanımı ile Zarazaga köprüsünü değerlendirmiştir. Köprülerin form, renk ve malzeme gibi ikonik özellikleri ile o kent ve bölge için landmark değerine dönüştüğü sonucuna varmıştır. Bu noktada Çanakkale geçiş mekanlarının güçlü ikonik özellikleri olmadığı gibi landmark niteliği taşımadığı sonucunu desteklediği görülmüştür.

Kent içinde geçiş mekanları tasarım, çevre ve kent birlikteliğinde ele alınması açısından değerlidir. Çanakkale gibi dünya sahnesinde yer edinen bir şehirde, kent dokusu ve kamusal etkileşimi güçlü tutan köprü tasarımlarını hayata geçirmek için uluslararası ya da ulusal çapta yarışma projeleri düzenlenmesi en etkili çözüm olarak görünmekte ve Çanakkale'de Sarıçay Nehri üzerinde tarz ya da yerel dokuyu yansıtan estetik bir geçiş mekânı görmek istemenin farkındalığı bu çalışma ile ortaya çıkmışolmaktadır.

\section{Bilgi Notu}

Makalede ulusal ve uluslararası araştırma ve yayın etiğine uyulmuştur. Çalışmada etik kurul izni gerekmemiştir.

\section{Yazar Katkısı ve Çıkar Çatışması Beyan Bilgisi}

Makalede tüm yazarlar aynı oranda katkıda bulunmuştur. Herhangi bir çıkar çatışması bulunmamaktadır.

\section{Kaynaklar}

Altaban, Ö. (2013). From town planning to urban design work-the dimensions to be considered. ICONARP International Journal of Architecture and Planning, 1 (1), 2-21. Erişim Adresi: 27.05.2021, https://iconarp.ktun.edu.tr/index.php/iconarp/article/view/33

Arslan, A. (2020). Bridges as city landmarks: A critical review on iconic structures. Journal of Design Studio, 2(2): 85-99.

Aslantaş, A. (1998). Kentsel Mekân Karakterinin Peyzaj Mekân Organizasyonu Açısından Değerlendirilmesi ve Sultanahmet Meydanı Örneği (Yüksek Lisans Tezi). İstanbul Teknik Üniversitesi Fen Bilimleri Enstitüsü, İstanbul. Erişim Adresi: 24.03.2021, https://tez.yok.gov.tr/UlusalTezMerkezi/

Başdoğan, S. ve Manisa, K. (2016). Kent merkezinde alternatif kamusal alan arayışı: Jean-Jacques Bosc Köprüsü Örneği. Yapı Dergisi, 56-62. Erişim Adresi: 07.06.2021, https://yapidergisi.com/kentmerkezinde-alternatif-kamusal-alan-arayisi-jean-jacques-bosc-koprusu-ornegi/ 
Bekçi, B. (2006). Peyzaj mimarlığında kişisel mekân kavramı ve kişisel mekân ölçme tekniklerinin değerlendirilmesi. İstanbul Üniversitesi Orman Fakültesi Dergisi, 56(2): 162-170. Erişim Adresi: 24.03.2021, https://dergipark.org.tr/tr/download/article-file/176232

Charles Köprüsü, Prag. (2021). Erişim adresi: 08.11.2021, https://www.afar.com/places/karluv-mostcharles-bridge-prague)

Çanakkale Atatürk Köprüsü yenileniyor. (28.11.2013). Erişim Adresi: 20.04.2021, https://emlakkulisi.com/canakkale-ataturk-koprusu-yenileniyor/211326

Çanakkale Dilsiz Haritası. (2021). Erişim Adresi: 21.10.2021, https://www.shutterstock.com/tr/search/canakkale+harita

Çanakkale Nüfusu. (2021). Erişim Adresi:21.10.2021, https://www.nufusu.com/il/canakkale-nufusu

ÇŞB. (2013). Çevre ve Şehircilik Bakanlığınca Onaylanacak Kentsel Tasarım Projelerinin Hazırlanmasına ve Değerlendirilmesine İlişkin Yönerge. Erişim Adresi: 27.05.2021, https://webdosya.csb.gov.tr/db/mpgm/menu/yonerge_02042018_20180403031242.pdf

Dizman, O. (2015). Geçişlilik Kavramının Mekâna Anlamsal ve Simgesel Yansımaları (Yüksek Lisans Tezi). Yakın Doğu Üniversitesi Fen Bilimleri Enstitüsü, Mimarlık Anabilim Dalı, Lefkoşa. Erişim Adresi: 07.04.2021, https://tez.yok.gov.tr/UlusalTezMerkezi/

Ertaş, M. Y. (2011). Evliya Çelebi Seyahatnamesi'nde yollar: Kaldırımlar, köprüler ve kervansaraylar. Pamukkale Üniversitesi Sosyal Bilimler Enstitüsü Dergisi, 10: 43-53.

Gürbüz, O. (2019). Sarıçay Havzası (Çanakkale) Florası (Yüksek Lisans Tezi). Çanakkale Onsekiz Mart Üniversitesi Fen Bilimleri Enstitüsü, Biyoloji Anabilim Dalı, Çanakkale. Erişim Adresi: 15.04.2021, https://tez.yok.gov.tr/UlusalTezMerkezi/

Gürkan, M. (2005). Çanakkale Sarıçay Deltası'nın Ornitho faunası (Yüksek Lisans Tezi). Çanakkale Onsekiz Mart Üniversitesi Fen Bilimleri Enstitüsü, Zooloji Anabilim Dalı, Çanakkale. Erişim Adresi: 15.04.2021, https://tez.yok.gov.tr/UlusalTezMerkezi/

Hakeim Köprüsü (Pont de Bir-Hakeim), Paris. (2021). Erişim adresi: 08.11.2021, https://www.pariste.net/bir-hakeim-koprusu-pont-de-bir-hakeim/

Hasol, D. (Der.) (1995) Ansiklopedik Mimarlık Sözlüğü (18. ed.). İstanbul: YEM Yayınevi.

III. Alexandre Köprüsü (Pont Alexandre III), Paris. (2021). Erişim adresi: 08.11.2021, https://www.pariste.net/iii-alexandre-koprusu-pont-alexandre-iii/

İnönü Köprüsü. (.2012, 24.09). Çanakkale Yeni Köprüsüne Kavuştu. Erişim Adresi: 20.04.2021, https://www.canakkaletravel.com/haber/canakkale-yeni-koprusune-kavustu-.html

Karagüler, S. ve Korgavuş, B. (2014). Kent Kimliğinin Kent Peyzajı Üzerinde Oluşturduğu Etkiler, Siluetler, Görünümler ve Dengeleri. Gazi Üniversitesi Fen Bilimleri Dergisi, 2(2):203-212. Erişim Adresi: 27.05.2021, https://dergipark.org.tr/tr/download/article-file/83808

Karakaya, B. (2013). Kentsel Peyzaj-Sürdürülebilirlik-Kent Silueti: Edirne Tarihi Çekirdeği (Yüksek Lisans Tezi). Trakya Üniversitesi Fen Bilimleri Enstitüsü, Mimarlık Anabilim Dalı, Edirne. Erişim Adresi: 24.03.2021, https://tez.yok.gov.tr/UlusalTezMerkezi/

Kaya, G. (2015). İstanbul'un Görselliğinde Görüntü-Kavram Yorumu Olarak Köprü (Yüksek Lisans Tezi). İstanbul Teknik Üniversitesi Fen Bilimleri Enstitüsü, Mimarlık Anabilim Dalı, İstanbul. Erişim Adresi: 24.11.2021, https://tez.yok.gov.tr/UlusalTezMerkezi/

Keleş, R. (2006). Kentleşme Politikası. İmge Kitabevi. Ankara.

Meteroloji Genel Müdürlüğü. (2021). Erişim adresi: 21.10.2021, https://www.mgm.gov.tr/veridegerlendirme/il-ve-ilceler-istatistik.aspx?m=CANAKKALE 
Odabaşı, S. (2005). Çanakkale Bölgesindeki Sarıçay Akarsuyu'nda Su Kalitesinin Araştırılması (Yüksek Lisans Tezi). Çanakkale Onsekiz Mart Üniversitesi Fen Bilimleri Enstitüsü, Su Ürünleri Anabilim Dalı, Çanakkale. Erişim Adresi: 15.04.2021, https://tez.yok.gov.tr/UlusalTezMerkezi/

Öncü, A. (2016). Çanakkale'de 1948-49 Yıllarında Atatürk Köprüsü. Erişim Adresi: 20.04.2021, https://www.canakkaletravel.com/haber/iste-ataturk-koprusu-68-yil-once-boyleydi.html

Öztürk, M. (2020). Çanakkale Sarıçay Havadan Görüntüleri. https://www.youtube.com/watch?v=U6IZqfw2OMY

Pakdamar, F. ve Aydın İpekçi, C. (2019). İstanbul'daki Kent içi köprülerin estetik açıdan incelenmesi. idealkent 27(10): 653-678. Erişim Adresi: 07.06.2021, https://dergipark.org.tr/tr/download/article-file/837839

Sağlık, A., Kartal, F., Şenkuş, D. ve Temiz, M. (2021). Çanakkale Sarıçay ve yakın çevresinde ekolojik tasarım önerileri. Kent Akademisi, 14 (3): 578-592.

Sağlık, E. (2020). Kent Günlüğünde Anlık Peyzajlar, Pandem!nsan, Ankara: Tam Pozitif Matbaa, 52-62. Erişim Adresi: 27.05.2021, https://avesis.comu.edu.tr/yayin/ac24251b-65fe-48fc-bc7293b3a2c2412a/pandemi-maskeli-peyzaj

Sarıçay Nehrinin havadan görünümü. (2021). Erişim Adresi: 02.11.2021, https://www.canakkaletravel.com/galeri/saricay.html

Şahin, K. (1983). Köprü/üst-geçit. Mimarlık, 189(3), 10-12. Erişim Adresi: 07.06.2021, https://dergipark.org.tr/tr/download/article-file/837839

Toprak, Z. (2003). Yenilikçi -Düşünen Kentler ve Toplumsal ilişskiler. Yerel Gündem 21 El Kitabı. İstanbul. Türk Dili Kurumu. (2021). Sözlükleri. Güncel Sözlük. Erişim Adresi: 07.06.2021, https://sozluk.gov.tr/

Türkiye Dilsiz Haritası. (2021). Erişim Adresi: 21.10.2021, https://www.cografik.com/turkiye-dilsizharitalari/

Uzun Köprü (Taş Köprü), Edirne. https://www.kulturportali.gov.tr/turkiye/edirne/gezilecekyer/uzun-kopru

(2021).

Velioğlu, S. (1996). Hareketin, mekânın ve kullanımın organizasyonu. Mimarlık, 270: 37-39.

Velioğlu, S. (2002). Bir mimari tasarım öğretimi modeli. Mimarlık Dergisi, 287. https://v3.arkitera.com/diyalog. php?action=displaySession\&ID=37\&year=\&aID=254

Yang, S. ve Huang, D. (1997). Aesthetic considerations for urban pedestrian bridge design. Journal of Architectural Engineering, 3-8. 